\title{
Testikulární lymfomy - editorial
}

\author{
Vít Procházka \\ Hemato-onkologická klinika LF UP a FN Olomouc \\ Komentář k | Editorial on \\ Motyčková M et al. Primární testikulární lymfomy. Vnitř Lék 2017; 63(6): 415-422.
}

Primární extranodální lymfomy varlete, též označované jako testikulární lymfomy, představují sice poměrně vzácnou kategorii nehodgkinových lymfomů, nicméně jde o jednotku mimořádně důležitou $z$ diagnostického, terapeutického i biologického hlediska. Histopatologicky se v drtivé většině jedná o difuzní B velkobuněčný lymfom, který představuje nejčastější subtyp lymfomů v České republice [1]. Hlavním biologickým rysem, který odlišuje lymfomy testes od většiny mimouzlinových forem lymfomů, je jejich vznik v terénu imunoprivilegované tkáně. Na takových místech nedochází při setkání s cizorodým antigenem $\mathrm{k}$ rozvoji zánětlivé imunitní reakce, ale naopak k rozvoji tolerance vůči danému antigenu. Je mimořádně zajímavé, že lymfomy imunoprivilegované tkáně - např. testikulární a primární lymfom CNS - mají velmi podobný genetický profil, který vede $\mathrm{k}$ expresi ligandů programované buněčné smrti (programmed-death ligand - PD) [2]. Interakce mezi PD ligandem na lymfomu a PD receptorem na efektorových buňkách imunitního systému vede $\mathrm{k}$ funkční inaktivitě T-lymfocytů. Tato osa je velmi dobře známa ze solidní onkologie a ukazuje se, že blokáda PD dráhy je velmi efektivní i v terapii rezistentních forem jak testikulárního, tak primárního lymfomu CNS [3].

Dalším specifikem lymfomů imunoprivilegované tkáně je přitomnost "fyzických bariér", které brání odtoku lymfy, čímž omezují prístup buněk imunitního systému. Tyto bariéry jsou pak v klinické praxi potenciálním terapeutickým problémem, protože znesnadňuji průnik konvenčních cytostatik do nádoru. Obě tyto charakteristiky se pravděpodobně podílejí na horších výsledcích léčby testikulárních lymfomů ve srovnání s nodálními formami difuzního velkobuněčného $B$ lymfomu.

V aktuálním čísle časopisu Vnitřní lékařství vychází důkladně zpracovaný přehledový článek, který pojednává o současném stavu vědění na poli testikulárních lym- fomů [4]. Motyčková a spoluautoři kladou důraz na praktickou stránku správné a časné diagnostiky. Zabývají se velmi správně zásadními aspekty stanovení prognózy nemocných - i s ohledem na fakt, že většina nemocných jsou muži vyššího středního věku. Pasáž o léčebných metodách je probrána velmi prakticky s důrazem na současná léčebná doporučení a důležitost profylaxe CNS postižení a vyvíjející se roli adjuvantní radioterapie.

Podobný přehledový článek, zpracováním vhodně zacílený na lékaře prvního kontaktu a všeobecné internisty, zlepší povědomí o této diagnóze a bezpochyby zvýší kvalitu primární péče o tyto nemocné. V současné éře nástupu nových biologických léčiv, cílené "geneticky navigované“ léčby a nových možností radioterapie vychází tato kvalitní rešerše současného stavu poznání testikulárního lymfomu právě včas.

\section{Literatura}

1. Trněný $M$, Klener jr. $P$, Pytlík R. Maligní lymfomy - minulost, současnost a budoucnost. Klin onkol 2015; 28(Suppl 3): 55-63. Dostupné z DOI: <http://doi: 10.14735/amko20153S55>.

2. Chapuy B, Roemer MG, Stewart C et al. Targetable genetic features of primary testicular and primary central nervous system lymphomas. Blood 2016; 127(7): 869-881. Dostupné z DOI: <http://doi: 10.1182/ blood-2015-10-673236>.

3. Nayak L, Iwamoto FM, LaCasce A. PD-1 blockade with nivolumab in relapsed/refractory primary central nervous system and testicular lymphoma. Blood 2017; 129(23): 3071-3073. Dostupné z DOI: <http:// doi: 10.1182/blood-2017-01-764209>.

4. Motyčková $M$, Vosáhlová $\mathrm{V}$, Belada $\mathrm{D}$ et al: Primární testikulární lymfomy. Vnitř Lék 2017; 63(5): 415-422.

\section{doc. MUDr. Vít Procházka, Ph.D.} $\triangle$ vit.prochazka@fnol.cz

Hemato-onkologická klinika LF UP a FN Olomouc www.fnol.cz

Doručeno do redakce 12.6. 2017 